\title{
Narratives and counter-narratives of Europe. Constructing and contesting Europeanity
}

"Europe " has never been as present in the media and in political discourse as it is today. The 2009 Eurozone crisis has sparked heated debates between partisans and opponents of austerity and the recent

The Author: Dr Céline CANTAT is a Visiting Research Fellow at Central European University, Budapest.

"negotiations » opposing the Greek Syriza-led government to European leaders and institutions have made the headlines for months. Yet, until recently, deeper questions regarding the nature of the European project, and the ideologies animating its trajectory and setting its goals, hardly ever seemed to be raised'. The negative outcome of the Syriza-led government's attempt at negotiating anti-austerity policies within the framework of the EU has started changing this. As it became clear that the EU would not allow the implementation of a programme challenging the prerogatives of neoliberal capitalism (including privatisation, fiscal austerity, deregulation, free trade, and reductions in government spending), a narrative presenting «Europe » as a capitalist, class project started to gain visibility.

Migration is also more than ever at the heart of debates around the future of the European project. In particular after more than 1,200 people died trying to reach its shores in the Spring 2015, the idea that Europe was experiencing a "migration crisis " gained currency in the media and political discourses. The notion of a crisis has produced representations of the recent movement of people towards Europe, and of deaths at the Union's borders, as "exceptional events " ${ }^{2}$. Yet border casualties have steadily increased over the last twenty years, in causal relationship with the reinforcement of the external borders of the European Union after the establishment of the Schengen Area. This situation has led migrants and their supporters to denounce and oppose violence in which "Europe " is involved at its borders.

In this article, I examine the relation to Europe and to narratives of European belonging of migration solidarity movements in the European Union. I start with an overview of the relevance of narra-

'DuRAnd Cédric, «Introduction » in DuRAnd Cédric (dir.), En finir avec l'Europe, Paris, La Fabrique, 2013, 160 p. ${ }^{2}$ Rajaram Prem Kumar, "Beyond crisis: Rethinking the population movements at Europe's border ». FocaalBlog, 19 October 2015, available online at: http://www.focaalblog.com/. 
tive approaches to understand the production of political norms and regimes of meaning as well as the way in which individuals negotiate and sometimes challenge these. I then set out to deconstruct and destabilise "official narratives» of the European project and call into question the internationalist nature commonly ascribed to the European Union. I propose to explore narratives of Europe and European identity from the perspective of the forms of marginalisation that they produce. I argue that official narratives of Europe have been based on a notion of European belonging premised on the idea of a distinct and recognisable European character that could set aside Europeans from non-Europeans. This narrative has led to the production of new figures of otherness at the regional level, among which the "migrant" has played a central role.

I then study the narratives of European belonging that are developed by people engaged in solidarity activism with migrants and raise the following question : how have pro-migrant activists engaged with the European project? Have they formulated discourses of Europe that propose alternative visions of European identity and belonging? Based on fieldwork conducted over a year and a half in three EU member states, I reach a conclusion that can seem at first paradoxical. I argue that pro-migrant struggles in the EU are increasingly connected and articulated at a pan-European, transnational level. Yet, I also contend that "Europe " as a narrative, a basis for alternative accounts of political subjectivity, is becoming increasingly irrelevant to migration solidarity struggles. While this might seem to identify a contradiction in the pro-migrant movement in Europe, I instead argue that it is the contradictions of the European project itself that can explain this apparent gap between pro-migrant actors' practices and narratives of Europe.

\section{Narratives and counter-narratives : an approach to politics and power}

At the most basic level, narratives are stories that individuals and institutions tell themselves and others about the world they live in and their place within it. Narratives organise sequences of historical events and the relations of causality between them in particular ways $^{3}$. At the individual level, narrative scholars argue that people

${ }^{3}$ SASSATELLI Monica, « Has Europe lost the plot? Europe's search for a new narrative imagination », Essay published by the European Cultural Foundation, 2012, available online at: http://www.narratives.eu/, p. 2. 
fashion stories to give meaning to their lives ${ }^{4}$. Through constructing narratives, individuals ascribe consistency and unity to their experiences and to the world around them ${ }^{5}$. Narratives are always constructed and communicated in contexts : they are shaped and in turn shape the social and political environments in which they are enunciated. In particular, they reflect, and at times challenge, norms of "tellability". It is precisely through the act of contesting what counts as tellable that counter-discourses develop. Yet, whether or not they intend to challenge the norms of the tellable, narratives are always political « even when they are personal, as they reflect the positionality of the speaker ${ }^{6}$.

\begin{abstract}
In the story which they weave, individuals reveal how they position themselves within the community in which they live, to whom or what they see themselves as belonging to/alienated from, how they construct notions of power, and the processes by which such power is negotiated. For individuals, political narratives are the ligaments of identity, revealing how one constructs the boundaries of, and the connections between, the self and the other ${ }^{7}$.
\end{abstract}

Narratives hence are the means through which individuals weave collective and public events into their personal existence and a tool through which their sense of belonging or membership to a group is expressed, assessed or contested. As argued by Molly ANDREWS ${ }^{8}$, narratives can play a key role both in broadening the personal and in individualising the collective, and they can catalyse political consciousness. In that sense, personal (micro) narratives are always in relation and in tension with official (macro) narratives of the social spaces within which individuals live. For Barbara CZARNIAWSKA, the ability of certain people or institutions to concoct narratives for others is precisely what power is about?. Deconstructing the production of macro narratives that count as official, exploring their relationship with the people they claim to speak about or for, is therefore an angle through which to apprehend relations of power in a given social and political context. It allows exploring, understanding and assessing the

${ }^{4}$ See McAdams Dan, « Personal Narratives and the Life Stories », in John O.P., Robin R.W. and Pervin, L.A. (dir.), Handbook of Personality: Theory and Research, New York, Guildford Press, 2008, (3 ${ }^{\text {rd }}$ ed.), pp. 242-62 and FreEMAN Mark and BROCKMEIER Jens, «Narrative integrity: Autobiographical identity and the meaning of the 'good life' ", in BrockmeIer Jens and CARBAUGH, Donal (dir.), Narrative and identity: Studies in autobiography, self and culture, Amsterdam, John Benjamins Publishing Company, 2001, pp. 75-99.

${ }^{5}$ BRUner Jerome, Acts of Meaning, Cambridge, Harvard University Press, 1990, 139 p. and COHLER Bertram, "Personal Narrative and the Life Course ", in BALTES P. and BRIMS O.J. Jr. (dir.), Lifespan Development and Behaviour, vol. 4, New York, Academic Press, 1982, pp. 205-241.

${ }^{6}$ ANDREws Molly, Shaping history: Narratives of political change, Cambridge, Cambridge University Press, 2007, 234, p. 9.

${ }^{8} \mathrm{Ibid}$.

9 CZARniaWSKa Barbara, Narratives in social science research, London, Sage, 2004, 168 p. 
construction, or attempts at constructing, particular regimes of meaning and specific sets of political arrangements and norms.

This paper applies a narrative approach to understand how the regimes of meaning underpinning "Europe " and "European integration " have been constructed. It does so by examining contrasting accounts of Europe and European identity. Addressing these questions from the perspective of individuals and organisations involved in supporting migrants and in contesting the borders of the European Union brings to the heart of the reflection the issue of "Europeanness ", or in other words of who counts as European in dominant narratives of the European project. This encourages us to critically analyse the relationship between official narratives of Europe and processes of marginalisation and of production of otherness at work in the European Union. The key question raised is whether those working in solidarity with people marginalised within and by official narratives of European identity have developed alternative accounts of Europe in order to frame and ascribe meaning to their activism.

Findings are based on fieldwork undertaken between 2012 and 2014 with eleven migration solidarity groups and campaigns in three EU member states - France, Italy and the UK. Groups working in solidarity with migrants in Europe are varied and plentiful. They range from established, Brussels-based organisations engaged in policy work and lobbying of EU institutions to research groups concerned with documenting and reporting on imprisonment practices in detention centres, and numerous community or activist groups providing day-to-day practical support to migrants. The main criterion to select participants was that groups and activists had to engage with European level migration-related politics, rather than solely in local or national contexts. In the context of this study, the emphasis was placed on established groups and organisations, which are publicly involved in pro-migrant work, yet these could include contentious political groups perhaps better apprehended as new social movements : decentralised, polycephalous and reticulated structures bringing together politicised actors in coalitions that can vary over time in order to promote particular discourses and objectives ${ }^{10}$.

A number of pivotal groups involved in migration solidarity activities at the European level were chosen as case studies. Three organisations are France-based associations" (Gisti, Fasti and Migreurop) whilst

\footnotetext{
10 FreEman Jo, «A Model for Analyzing the Strategic Options of Social Movement Organization », in FreEman Jo (dir.), Social Movements of the Sixties and Seventies, New York, Longman, 1983, pp. 193-210.

"Under French law, an association is the agreement through which two or more people decide putting in common, in a permanent fashion, their knowledge and/or activities for an objective which is not profit-oriented (own translation from French law on association from 1901).
} 
one, the Migrants' Rights Network (MRN), is a UK-registered charity. No Borders, No One Is Illegal (NOII) and Stop Deportation are unregistered activist networks. Finally, PICUM is a Brussels-based NGO and European Alternatives bills itself a transnational membership organisation. Fieldwork was also conducted with two pro-migrant campaigns, Boats 4 People (B4P), a solidarity flotilla in the canal of Sicily, and When You Don't Exist (WYDE), a campaign organised by Amnesty International to defend the human rights of migrants, refugees and asylum-seekers in Europe and at its borders.

Observation (participant observation whenever possible) was carried out and interviews were conducted with key activists and staff members, who were selected to reflect the diversity of pro-migrant activists in terms of age, gender, geographical origins and political backgrounds. In line with narrative approaches, interviews were loosely directive and particular attention was paid to the subject positions enacted by both interviewee and interviewer in the context of the interview. A guiding concern throughout the fieldwork process was participants' understanding of the European project and its official narratives.

\section{Official narratives of European integration}

In official accounts, "Europe " is presented as an internationalist or a post-national project, confining to the past the excesses of nationalism and national rivalries and promoting cooperation and friendship among its member states and their people. The EU website describes the benevolent founding fathers behind European construction as "visionary leaders" who offered "their energy and motivation " so that European citizens could enjoy " a sphere of peace and stability " now embodied in " a peaceful, united and prosperous Europe ».

Yet a number of scholars have offered contrasting accounts of the process of European construction. British economic historian Alan MILWARD argues that the origins of the European Community are one of the most "ill-understood aspects of recent history and present political life $n^{12}$. According to him, this is because the European Community (later European Union) has been presented as " in antithesis to the nation-state $"^{13}$. In reality, he suggests, the main objective behind the establishment of the European Community was the rescue of Western European nation-states in 
the aftermath of the Second World War. Western Europe emerged from the two World Wars devastated. The international environment was changing and the USA and their project of a capitalist West were quickly rising to hegemony. In this context, capitalist classes realised that it had become necessary for national economies to pursue their interests across borders in order to survive $^{14}$. The European Community allowed transnational cooperation between national economies and was therefore " an integral part of the reassertion of the nation-state as an organisational concept » in this part of the world ${ }^{15}$.

In this sense, the post-war nation in Europe was characterised by an inherent instability insofar as « it had to be internationalised at certain points to survive $~_{16}$. Indeed, from its inception, the European Community was used as an arena for both cooperation and competition between member states. President DE GAULLE's « empty chair policy ", whereby he refused to send French emissaries to Brussels until his demands were met, is a telling example of how nation-states manoeuvred between the still firmly national structure of capital and the growing need for Europeanisation. Since its early days, the EC was thus marked by tension and even contradiction, reflecting the relation between national organisation of capital and the tendency towards its internationalisation which have marked the process of European integration. Rather than a natural process of supranational reconciliation, it was a project born out of political and economic power relations at work on a global scale in the post-war era.

Official narratives tend to conceal the complex and contestatory origins of the European project, which I argue can be highlighted by paying attention to the political and economic context of their production. This argument leads us to explore alternative histories of the construction of the European Community/Union, which in turn bring us to consider counter narratives.

\section{« You don't fall in love with a common market ॥}

By the 1970s, the post-war Keynesian compromise was quickly losing ground to neoliberal approaches and the so-called " golden age " of capitalism seemed to be coming to an end. In the USA, the hundred-year period of rising wages was permanently over, while privatisation of production and deregulation of markets were reaching

${ }^{14}$ HARMAn Chris, "The Common Market ", International Socialism, 1971, n 49, pp. 6-10.

${ }^{15}$ Milward Alan, The European Rescue of the Nation State, op. cit., p. 3

${ }^{16}$ Ibid., p. 44. 
unprecedented levels ${ }^{17}$. In the UK, the 1979 appointment of Margaret THATCHER as Prime Minister inaugurated a programme of privatisation, market deregulation, liberalisation and trade union marginalisation. This reorganisation of traditional economic sectors (and complete dismantling of others) in the UK was paralleled by similar restructuring in other Western European countries ${ }^{18}$. In line with neoliberal principles, member states were also trying to reduce government spending at a time when unemployment was massively on the rise. In this context of economic downfall, the EC became the target of increasing hostility both from people of the member states and from segments of national capitalist classes ${ }^{19}$.

In spite of growing Euroscepticism, European politicians, such as Helmut KOHL and Jacques DELORS, remained firmly convinced that more integration was needed for European economies to survive the crisis. Yet, in this context, pushing for further Europeanisation was rendered difficult and the issue of popular mistrust toward the European Union became an object of growing concern for partisans of the EC. The idea of a "legitimacy deficit » of the Community gained currency and attention started being paid to "European public opinion ". The 1973 introduction of the Eurobarometer, a tool aimed at monitoring popular feelings toward the Community, illustrates the rising anxiety of European architects and the challenges they faced in securing consent from the people of the member states $^{20}$. The objective of the Eurobarometer was twofold. While the polling system was presented as a means to learn more about people's opinions in order to inform policy, its creators also saw it as a performative tool that would « help reveal Europeans to each other $n^{21}$.

In other words, as further economic and political integration was encouraged by leading European politicians, a fear emerged that it would be limited unless people started feeling «more European ». This did not entail detaching people from their national allegiances. As mentioned, the EU is a project that exists and functions through national structures and institutions. To an extent, this means that the European project can function without the same degree of allegiance and sup-

${ }^{17}$ Wolff Rick, «In Capitalist Crisis, Rediscovering Marx », in Musto Marcello. (dir.), Marx for Today, London, Routledge, 2012, p. 146.

${ }^{18}$ Marfleet Philip, "Nationalism and Internationalism in the New Europe ", International Socialism, 1999, $n^{\circ} 83$.

19 Most notably in the British Conservative Party.

${ }^{20}$ SIGNORELLI Salvatore, The EU and public opinions: A love-hate relationship?, Studies \& Reports, Notre Europe - Jacques Delors Institute, 2002, 82 p., available online at: http://www.institutdelors.eu/ (accessed 10 January 2015) 
port as the nation-state. It does, however, require a level of legitimacy in its operationalisation and for its continuation. Yet, as put by one of Europe's architects, Jacques DELORS, «you don't fall in love with a common market ; you need something else $"^{22}$. In a formation as contradictory as the European Community, what ideological resources can be mobilised to produce a sense of unity? As argued by Philip MARFLEET:

The EC was not a nation-state in which an ideology of «belonging " could be mobilised during periods of instability or crisis. It lacked a framework for nationalism : myths of common origin, a national religious community, a monarchy. The Community had been constructed upon nation-states which had emerged from centuries of local rivalry: there could be no reference point for an EC patriotism, no European Jeanne d'Arc ${ }^{23}$.

\section{The politics of Europeanism}

One strategy deployed by Europe's architects to garner support and trigger unity has been to insist on the need for a cultural European identity to emerge. In this vein, a set of symbols aimed at signifying a common European history and culture, and at triggering affection toward Europe among the people of its member states, have been introduced. These include a European anthem (the prelude to the "Ode to Joy " from Beethoven's ninth symphony, chosen in 1972), a European flag and "Europe Day " (adopted respectively in 1983 and 1985) as well as a motto ("Unity in Diversity ") ${ }^{24}$. In addition, a set of cultural activities supposedly related to Europe was implemented and a number of cultural institutions aiming at promoting European ties were established. This new European culture brought together an odd mix of populist initiatives, with little anchorage in the region's history, and symbols of high culture, with little chance of triggering popular attachment. Gérard DELANTY describes such attempts at producing European cultural identity as:

[...] pathetic exercises in cultural engineering: the Eurovision Song Contest, Euro-Disney, the Ecu, the Annual European City of Culture and the cultural apparatus of the new institutions was not the stuff out of which new symbolic structures could be built ${ }^{25}$.

Ole WAEVER and Morten KELSTRUP label this a "balloons and flags" strategy aimed at making the EC more appealing and, maybe, at inducing a degree of affection towards it, but with little actual significance

\footnotetext{
${ }^{22}$ LAFFAN Brigit, "The Politics of Identity and Political Order in Europe », Journal of Common Market Studies, 1996, vol. 34, nº, p. 95.

${ }^{23}$ MARfLeEt Philip, "Nationalism and Internationalism in the New Europe ", op. cit.

${ }^{24}$ EUROPEAN UNION, EU symbols, available on the following website: http://europa.eu/.

${ }^{25}$ DeLANTY Gerard, Inventing Europe : Idea, Identity, Reality, London, Macmillan, 1995, p. 147.
} 
in terms of people's identification with Europe ${ }^{26}$. Gérard DELANTY also argues that the mobilisation of emblems inspired from the traditional appendage of nationalism is largely inadequate and lacks both meaning and emotional impact ${ }^{27}$.

As part of this existential quest for meaning, there was also a multiplication of narratives keen on tracing back the roots of the Union to ancient times, drawing on European past to present recent territorial transformations as the linear continuation of a European historical and cultural spirit in motion. A rather crude example was Jordan's assertion that "Europe is a culture which occupies a cultural area ${ }^{28}$. But we can also note, particularly since 1989, a sharp increase in a "cultural and historical literature on the question of Europe ${ }^{29}$. He claims that:

\begin{abstract}
From the medievalist Jacques Le Goff to Rémi Brague, professor of Arabic philosophy, the "postmodern » conservative Peter KosLOWSKI

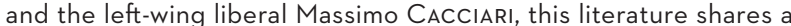
specific interest in a historiologically decipherable «identity ", as well as in cultural-historical prototypes of Europe which are supposed to allow conclusions - or rather preconceived judgements - on the future shape of the EU.
\end{abstract}

A common trait of these types of research is that a set of historical events and ideas are drawn upon to create a coherent narrative of the construction of Europe as an entity. They also sanctify Europe, upholding it as a desirable model with universal validity. Tony JUDT praises "Europe's emergence in the dawn of the $21^{\text {st }}$ century as a paragon of international virtues : a community of values held up by Europeans and non-Europeans alike as an exemplar for all to emulate ${ }^{30}$. Perry ANDERSON also comments on how in the UK no group expressed better the mythology of Europeanism that was created to support and trigger popular affection toward the EU project than New Labour ${ }^{31}$. In Why Europe Will Run the $21^{\text {st }}$ Century, Mark LEONARD invites his readers to share his dream : "[i]magine a world of peace, prosperity and democracy... What I am asking you to imagine is the «New European Century "... ". ${ }^{32}$ Mark LeONARD goes on to add that:

${ }^{26}$ WAEver Ole and Kelstrup Morten, «Europe and its Nations: Political and Cultural Identities », in WAEver Ole, Buzan Barry, Kelstrup Morten and Lemaitre Pierre (dir.), Identity, Migration and the New Security Agenda in Europe, London, St. Martin's Press, 1993, p. 67.

${ }^{27}$ DELANTY Gerard, Inventing Europe : Idea, Identity, Reality, op. cit.

${ }^{28}$ Quoted in PAASI Anssi, « Europe as a social process and discourse : Considerations of place, boundaries and identity ", European Urban and Regional Studies, 2001, vol. 8, issue 1, pp. 7-28.

${ }^{29}$ NOWOTnY Stefan, «Ethnos or Demos? », European Institute for Progressive Cultural Policies, 2000, available at: http://eipcp.net/.

30 JUDT Tony, Postwar: A History of Europe since 1945, Portsmouth, Heinemann, 2005, p. 798. 
Europe represents a synthesis of the energy and freedom that come from liberalism with the stability and welfare that come from social democracy. As the world becomes richer and moves beyond satisfying basic needs such as hunger and health, the European way of life will become irresistible ${ }^{33}$.

For these authors, the history of Europe is one of enlightenment, attachment to liberties and social justice, and the European Union is the logical and praiseworthy expression of the values of the European space. These narratives form what I call the dominant discourse on Europe. They attempt to identify common historical and cultural features bringing together Europeans and produce a discourse on «Europeanity».

\section{Europe and its 0thers}

In contrast to essentialist narratives, a number of scholars have elaborated critical reflections on attempts at forming a European identity. Gerard DELANTY claims that defining and representing Europe has long relied on representations of what it is not and of its boundaries, and has been characterised by the lack of European unity besides that achieved through adversity ${ }^{34}$. He suggests that Europe's cultural and political identity has historically been articulated in its relation to Other(s), and through a process of constant reconstruction of «ins " and «outs" reflecting particular sets of power relations at given points in time. For Gerard DELANTY, ideas of Europe have been characterised by their production of differences, on both geographical and « mythological " terms. A few years into the making of the EU, his conclusion is that dynamics of exclusion are more than ever at work in Europe:

[W] ho is a European is largely a matter of exclusion, and in the dichotomy of self and Other which constitutes the discourse of European identity, Europeanity is constructed in opposition with the non-European, in particular Islam. This sense of the uniqueness of the European is today emerging as a basis for a kind of supranational identity and citizenship which European integration does not have ${ }^{35}$

In a similar vein, Philip MARFLEET looks back at the history of the notion of European civilisation ${ }^{36}$. He identifies the $18^{\text {th }}$ century Enlightenment as a turning point when ideas of Europe started to take a specific political and cultural shape. To a large extent, these new ideas of Europe resulted from the experience of European bourgeois classes in the world and were closely related to colonial expansion, of which bourgeois merchants were prime beneficiaries. The idea of

\footnotetext{
${ }_{33}$ Anderson Perry, The New Old World, London and New York, Verso, 2010, p. 47

${ }^{34}$ DeLANTY Gerard, Inventing Europe : Idea, Identity, Reality, op. cit.

35 Ibid., p. 9.

${ }^{36}$ MARfLeEt Philip, "Nationalism and Internationalism in the New Europe », op. cit.
} 
a superior European civilisation often provided a moral legitimisation for colonial ventures and the oppression of people seen as inferior. Philip MARFLEET concludes that " [t]o this extent, the idea of Europe was one generated by those who wished to assert a universal mission for capitalism ${ }^{37}$.

Gerard Delanty and Philip Marfleet show that this early "Europeanism " already bore heavy contradictions in the context of the intense rivalries between European colonial powers. Different ideas of Europe, often merging features of national discourses with mythological accounts of its Greek and Latin roots, were mobilised by national ideologies in order to serve their own interests. Gerard DELANTY refers to colonial France's concept of Europe as « a thoroughly French affair ... proclaim[ing] 'the superiority of the European religion, the white race and the French language' ${ }^{38}$. In the first half of the $20^{\text {th }}$ century, it is the fascist vision of a culturally uniform, unified European continent which gained prominence over other visions of Europe. Hitler's "European New Order ", which would be imposed on the world by Nazi Germany, entailed the supremacy of the "master race " and the physical annihilation of those considered as "racially inferior ». For Gerard DELANTY, this was "the apotheosis of the idea of Europe ${ }^{39}$.

Throughout the Cold War, Europe's obvious Other was the Soviet system, and the notion of Western civilisation bringing together Europe and the USA against the Communist enemy was a crucial part of Western propaganda. With the collapse of the Soviet Union and the disappearance of its key ideological reference point, Europe yet again had to reinvent its Other so as to define itself. In this context, Philip MARFLEET looks at the part played by Samuel HUNTINGTON's theory of a "clash of civilisations" in the construction of a new sense of Europeanity ${ }^{40}$. The "clash theory " relies on a primordialist reading of history and of the world, seen as divided into hermetic areas of "culture ». Those belonging to other "civilisations" are constructed as absolute Others. According to Philip MARFLEET, it is in the mirror of this renewed otherness that European politicians have tried to anchor an ever-fleeting sense of a European identity in the post-Cold War era.

The end of the Cold War also inaugurated a new era of global migrations. In the West, the implementation of neoliberal policies and the reorganisation of economies and labour regimes led to a steep rise

\footnotetext{
37 MARfLeEt Philip, « Nationalism and Internationalism in the New Europe », op. cit.

${ }^{38}$ DeLANTY Gerard, Inventing Europe : Idea, Identity, Reality, op. cit., p. 71.

39 Ibid., p. 72.

${ }^{40}$ Marfleet Philip, «Nationalism and Internationalism in the New Europe », op. cit. and Marfleet Philip,
} 
in unemployment. This had a negative impact on the numerous migrant workers who had been encouraged to come to Western Europe to join the lower segments of its labour markets ${ }^{41}$. Concomitantly, migratory movements from the Global South were intensifying in a context marked by the failure of post-independence states to bring about economic growth. In many instances, this was directly related to the shortcomings of structural adjustment programmes implemented in Africa, Asia and South America under the auspices of the International monetary Funds and the World Bank. In this context, migrants and migration became increasingly important focuses of European debate and policies. In the decades after the wars, the legal status of working migrants was not a salient political issue in Western European countries. But with the start of the economic depression in the 1970s, followed by the fall of the Soviet Union, migrants became key figures of difference against which people of the EU member states could be argued to share a common "Europeanity".

These observations are confirmed by the work of Liz FEKETE. Looking at recent developments, this author examines the rise of "xeno-racism» :

Today, the threat posed by 125 million displaced people, living either temporarily or permanently outside their countries of origin has replaced that which was posed by communism ... [A] whole new anti-refugee discourse has emerged in popular culture. Those seeking asylum are demonised as bogus, as illegal immigrants and economic migrants ... And it is this ... that signals the emergence of a new racism ${ }^{42}$.

She evidences the intrinsic relation linking media, legal, discursive and physical practices of xeno-racism in Europe, and the strengthening of a shared sense of European belonging and identity as a basis for European citizenship. In doing so, she demonstrates the importance and the instrumentality of the (produced) figure of the forced migrant as an ideological cog of the European discourse on identity and belonging.

The EU project does not only erect external borders of absolute otherness but also creates internal borders. The use by mainstream media ${ }^{43}$ of the derogatory acronym PIGS (Portugal, Italy, Greece and Spain) to refer to the Mediterranean countries of the EU is also illustrative of an operation of marginalisation of the peripheries of the new

\footnotetext{
${ }^{41}$ Horvath Kenneth, «Policing the Borders of the 'Centaur State' : Deportation, Detention, and Neoliberal Transformation Processes-The Case of Austria », Social Inclusion, 2014, vol. 2, n` 3, p. 116.

${ }^{42}$ Fekete Liz, "The Emergence of Xeno-Racism », Race \& Class, 2001, vol. 43, n², p. 23.

${ }^{43}$ See for example DAWBER Alistair, "While Greece flails, are the rest of the stricken Pigs taking off? ", The Independent, Friday 20 February 2015, available on the following website : http://www.independent.co.uk/.
} 
Europe. Similarly, if Europe's new racism primarily targets migrants coming from outside the EU, it also identifies «internal enemies". Roma people, who were the victims of aggravated persecution in the 1920 s and 1930s, and of Nazi oppression in the 1940s, have faced new forms of extreme marginalisation in the last two decades. In Central and Eastern Europe, the post-1989 transition has led to such heightened racism and violence against Roma communities that Kenrick speaks of " a new genocide against Gypsies " ${ }^{44}$. Pogroms and mob attacks against Roma people have multiplied in Romania, Bulgaria, Hungary and the Slovak and Czech Republics. In 1993, the mayor of a Slovak village stated : "I am not racist, but some Gypsies you would have to shoot ${ }^{45}$.

In Western Europe, Roma migrants have also been subject to incredible levels of media hostility as well as to physical abuse. Most Roma people coming to claim asylum in Western Europe have been expelled, in spite of many of them being EU citizens. France in particular has engaged a policy of systematic deportation of Romani communities, under the pretext of removing "illegal camps" across the country ${ }^{46}$. This, ironically, took place while the EU was engaged in efforts to secure Roma rights in Eastern and Central European countries, which proves the full awareness of Western European politicians deporting Roma migrants of the persecution facing these communities. Hence, the operationalisation of this discourse of othering also has implications inside national societies. Increasingly, nationalist xenophobic discourses are framed around notions of Europeanness or European civilisation. Recently, French Front National's leader Marine LE PEN took position in favour of Russian President PUTIN over the crisis in Ukraine, on the basis that he was " a defender of the Christian heritage of European civilisation ${ }^{47}$. Similarly, Nigel FARAGE, UKIP's leader, in the wake of the Charlie Hebdo attacks in which several French cartoonists were killed in January 2015, claimed that it was necessary to defend «Europe's JudeoChristian culture ${ }^{48}$. In a similar vein, Hungarian Prime Minister, Viktor

${ }^{44}$ KENRICK Donald, « Gypsies: How many roads? Life on the edge ", Index on Censorship, 1998, vol. 27, n 4 , pp. 55-69.

45 YOUNGE Gary, "Slandering Britain's Roma isn't courageous. It's racist », The Guardian, 17 November 2013, available on the following website: http://www.theguardian.com/.

${ }^{46}$ BBC, "French ministers fume after Reding rebuke over Roma ", 15 September 2010, available on the following website: http://www.bbc.co.uk/.

${ }^{47}$ " $€ 4 \mathrm{Om}$ of Russian cash will allow Marine Le Pen's Front National to take advantage of rivals' woes in upcoming regional and presidential elections ", The Independent, 27 November 2014, available on the following website : http://www.independent.co.uk/. 
OrBAN has called for "Europe to be preserved for the Europeans ${ }^{49}$. This discourses also routinely target groups such as children of migrants, European Muslims and, as mentioned, Roma communities.

\section{Building the Fortress?}

The centrality of the migrant Other and of the border in the EU identity building process is also visible in another way. One of the key material embodiments of European unity is the suppression of national border controls between member-states, making it possible for EU citizens to travel across the EU without a passport and visa ${ }^{50}$. This free travel zone, named the Schengen Area after the Treaty that created it, currently comprises the territories of 25 European countries, including three non-EU member-states (Iceland, Norway and Switzerland). Only two of the EU member-states, Ireland and the UK, have decided to opt out of Schengen (though the Treaty has been integrated into EU law) and three EU member-states (Bulgaria, Cyprus and Romania) have not yet implemented it, mostly due to restrictions towards the freedom of movement of their citizens imposed by other EU countries.

The abolition of intra-EU national borders through Schengen has been heralded as the ultimate illustration of the progressive potential of the Union. However, a closer examination of the EU today reveals a very different picture that contradicts the idea that European nations and nationalisms are being replaced with cosmopolitan forces. In fact, Schengen operates as a single state for international travel and it has matched the elimination of internal borders with a reinforcement of Europe's external borders (those with non-EU member-states). This process has been so intensive that the term "Fortress Europe " has been coined to describe this process.

A powerful metaphor for those meaning to highlight the dynamics of exclusion in the EU and at its borders, "Fortress Europe " does not however fully capture the complex developments taking place at the EU's borders and beyond. Rather than hermetically closing the space of Europe and strictly keeping migrants out, the borders of the EU operate a process of differential and subordinated inclusion ${ }^{51}$. The bordering of Europe relies on two complementary processes. On the one hand, the EU has been

${ }^{49}$ KoszTıcsák Szilárd, "PM Orban: Europe should be preserved for Europeans », Hungary Today, 26 July 2015, available on the following website $:$ http://hungarytoday.hu/.

${ }^{50}$ This is also generally allowed for residency permit holders in the member states.

${ }^{51}$ MezzAdRa Sandro and NeILSON Brett, "Borderscapes of Differential Inclusion », in Balibar Étienne, MezZadRa Sandro and Samaddar Ranabir (dir.), The Borders of Justice, Philadelphia, PS, Temple University Press, 2011, pp. 181-203. 
externalising its borders and has developed a regime of migration control that extends way beyond the limits of its territory, in particular with agreements through which third countries play an active role in preventing " unauthorised " departures. On the other hand, the external borders of Europe have been reproduced inside its territory. The multiplication and systematisation of immigration detention centres, producing areas of suspended spatiality where people are kept at the margins, neither inside nor outside the physical territory, are a telling example of this process. Another characteristic of the EU border regime is the process of securitisation it undergoes with the multiplication of advanced border surveillance systems and technologies ${ }^{52}$. Increasingly, the securitisation of migration involves private actors such as security companies involve in developing surveillance technologies or running detention facilities. These also represent coercive modes of management of people's mobilities. They allow the policing of the EU's borders "from a distance" and in an increasingly anticipative and individualised fashion, through the gathering of personal information and biometric data about would-be migrants.

These developments are supported, and further articulated, across a highly complex topology of visas and residence permits, with associated rights and restrictions, which produce new modalities of differential inclusion. Following Étienne BALIBAR and Sandro MEZZADRA ${ }^{53}$, we can consider these movements of border shifting as the most visible forms of a wider and more complex process of production of a "Europe of borders » or, in Étienne BALIBAR's terms, a «European apartheid " ${ }^{54}$. For Mike HAYNES, " it is here, in both the ideas and practice of immigration control, perpetuated both at the intergovernmental level and at the level of the EU, that the new 'Europe' is being forged, a much as in the debates and celebrations of internal unity ${ }^{55}$.

\section{Solidarity with migrants}

In spite of the construction of this exclusionary regime, alternative discourses that acknowledge the legitimacy and necessity of migration, and sometimes radically defend freedom of movement,

${ }^{52}$ BIGO Didier, et al., "Borders and Security : the different logics of surveillance in Europe ", in BonJour Saskia, REA Andrea and JACOBS Dirk (dir), The Others in Europe, Brussels, Institut d'Etudes Européennes, 2011, pp. 1-30.

${ }^{53}$ Balibar Étienne and Mezzadra Sandro, « Borders, Citizenship, War, Class. A dialogue moderated by Manuela Bojadžijev and Isabelle Saint-Saëns ", New Formations, 2006, n 58, pp. 10-30.

${ }^{54}$ Balibar Étienne, We, the People of Europe? Reflections on Transnational Citizenship, Princeton, Princeton University Press, 2003, $304 \mathrm{p}$. 
have emerged in segments of the European population. Instances of migrant-led acts of resistance and protest have also taken place across EU member states, often encouraged and supported by European citizens.

This is not an exceptional occurrence : ideological campaigns promoting difference have often produced contradictory outcomes ${ }^{56}$. On repeated occasions, attempts by states or xenophobic politicians to formalise exclusion have led to campaigns of solidarity and public support towards non-nationals. This history of solidarity has gone largely unrecorded ${ }^{57}$. Yet, from the defence of European refugees by the Chartist movement to campaigns of solidarity with Eastern European Jews fleeing persecution from the Russian Empire in $19^{\text {th }}$ century Britain, there exists a long history of people mobilising in support of non-nationals. When FRANCO's military bombed the village of Guernica, 20,000 Basque children found refuge in several European countries, including France, Belgium and Britain, in spite of governments and ruling classes expressing concerns as these children came from socialist, anarchist, communist or left republican families ${ }^{58}$.

Since the 1980s, as new patterns of exclusion spread across Europe, campaigns of solidarity with migrants also emerged. The French sans-papiers movement of the 1990s attracted significant levels of support both in France and across Europe. Starting as an appeal for the regularisation of undocumented migrants, it grew into a movement opposing immigration controls and calling for the freedom of movement. Their mobilisation was sustained for almost three years. It brought together citizens and non-citizens in a spirit of solidarity that acknowledged migrants' individual agency and respected their autonomy. Its legacy continues to this day in the form of hundreds of sans-papiers collectives in France. Other struggles inspired by the sans-papiers movement have grown across Europe, including in Belgium and Switzerland.

I distinguish between sporadic calls for «better border policies " which emerge from national and European authorities usually in response to particularly visible tragedies, such as the October 2013 shipwreck near Lampedusa that cost the lives of over 400 people, and pro-migrant activism. Indeed, as the human cost of the EU border regime keeps rising, there has been some concern among representatives of the European Commission and the member states regar-

\footnotetext{
${ }^{56}$ Marfleet Philip, Refugees in a Global Era, op. cit., p. 282.

${ }^{57}$ Ibid., p. 283.

${ }^{58}$ LagaretTA Dorothy, The Guernica Generation: Basque Refugee Children of the Spanish Civil War, Reno, University of Nevada, 1985, 396 p.
} 
ding the situation at "Europe's borders". The debate usually revolves around the question of whether the EU should implement search and rescue (SAR) operations. SAR operations allow intercepting migrants at sea and hence, it is claimed, can prevent further deaths. They are generally military operations which mix security objectives and humanitarian activities. In this sense, they do not call into question the securitisation of borders and the criminalisation of migration, responsible for pushing people towards dangerous journeys in the first place. By associating rescue activities with a military perspective they in fact confirm the perception of migration as a risk and a security issue. Further, the sensors, radars, satellite platforms and surveillance drones routinely used in order to detect, trace and prevent irregular migrations are now presented as equally relevant responses to humanitarian concerns.

\section{The Changing Context of Migration Solidarity Practices}

While solidarity movements opposing racism, immigration controls and discrimination against migrants have been important aspects of the Western European political scene for decades, the groups and movements I am looking are different in important respects to previous forms of migrant solidarity. This concerns both groups created recently to address issues related to the EU border regime and those that existed before in local and national contexts and have now engaged with European issues. All have been shaped by the new political and social context of migration in Europe. Here, I would like to mention three recent developments that have affected the political identities of pro-migrant groups and activists.

First, since the 1980s, there has been an irruption of migrant-led struggles in several Western European countries, which have brought a new migrant subjectivity into the political discourse associated with migration. The affirmation by non-citizens of their subjecthood and of their « right to have rights $»^{59}$ has given rise to new forms of political subjectivity of non-citizens and has disrupted established norms about political participation, democracy, civil rights, and citizenship ${ }^{60}$. These

${ }^{59}$ ARENDT Hannah, The origins of totalitarianism, New York, Harcourt, Brace and Jovanovich, 1973, 576 p. and RANCIĖRE Jacques, "Who is the Subject of the Rights of Man? ", South Atlantic Quarterly, 2004, vol. 103, n० 2 and 3, pp. 297-310.

${ }_{60}$ WRIGHT Cynthia, "Moments of Emergence : Organizing By and With Undocumented and Non-Citizen People in Canada after September 11 », Refuge, 2003, vol. 21, p. 5 and Nyers Peter, «Abject Cosmopolitanism: The Politics of Protection in the Anti-Deportation Movement ", in DE Genova Nicholas and PeUtz Nathalie (dir), The Deportation Regime: Sovereignty, Space, and the Freedom of Movement, Durham NC, Duke University Press, 2010, $520 \mathrm{p}$ 
"acts of citizenship " ${ }^{67}$ by non-citizens pose normative and political challenges to traditional political assemblages and migrants emerge as key protagonists of a number of global struggles around freedom of movement, workers' rights and social protection ${ }^{62}$. The French sans-papier movement of the 1990s is a well-known example of this.

The intervention of migrant-led initiatives has affected the ways in which pro-migrant groups operate and conceptualise their work. Though the relationship between these different groups varies, the conceptual recognition of a subjectivity and agency of migrants, as a diverse and heterogeneous group, is unanimously asserted.

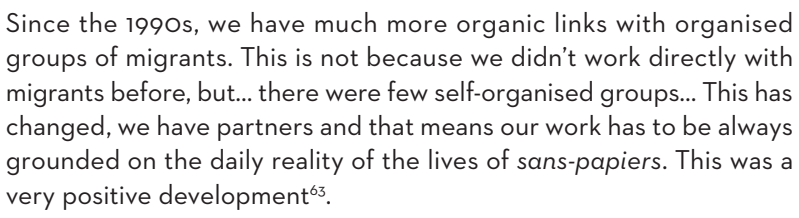

The way in which migrants are objectified by mainstream representations speaking of "flows", statistics and numbers whose presence results from "push and pull " factors, is also denounced and challenged $^{64}$. A participant from Italy describes several issues with the mainstream media's language around migration :

First, the use of shocking news ... The phenomenon of irregular migrations is represented as a phenomenon of frightening proportions ... Second, the use of a terminology that involves contempt, that dehumanises, that deprives of dignity ... Also, the abusive use of a military terminology like, for instance, emergency, alarm, siege, invasion, landing. The message reaching the public opinion is that Italy is at "war " and that migrants are " the enemy "... Then, the use of words denoting something abnormal or extraordinary. For instance : biblical exodus, humanitarian tsunami, earthquake, human weapons. Finally, there is a total lack of care and knowledge about the situation in the countries of origin of migrants. This calls into question specific political and historical responsibilities of Italy towards countries such as Libya, Somalia, Eritrea [...] which have a colonial past with Italy ${ }^{65}$.

The second development is the emergence, since the late 1990s, of various contentious political and social interventions that can be loosely brought under the label of anti- or alter-globalisation politics. The inscription of migration-related struggles within the framework of the

\footnotetext{
${ }^{61}$ ISIN Engin and NIELSEN Greg, Acts of Citizenship, London, Zed Books, 2008, 303 p.

${ }^{62}$ MCNevin Anne, "Political Belonging in a Neoliberal Era: The Struggle of the Sans-Papiers », Citizenship Studies, 2006, vol. 10, n², pp. 135-151.

${ }^{63}$ Chantale, Interview with Céline CANTAT, 17 September 2012.

${ }^{64}$ WALTERS William, «Expulsion, Deportation, and the International Police of Aliens », Citizenship Studies, 2002, vol. 6, n³, pp. 265-92

${ }^{65}$ Marco, Interview with Céline CANTAT, 21 July 2012.
} 
anti-globalisation movement has not been an obvious and unproblematic development. In fact, the earlier forms of transnational anti-globalisation political interventions largely left migration issues aside, as illustrated for example by the absence of specifically migration-focussed workshops in the earlier editions of the World Social Forum. This was mostly due to the fact that the "globalisation " of immigration controls was not as obvious as that of trade and finance and is still characterised by a complex intertwining of national and supranational practices. However, both analytically and practically, this gap has been significantly bridged and migration has been firmly inscribed on the WSF's agenda since at least its fifth edition in 2005. In Europe, Sandro MEZZADRA notes that the 2001 Genoa protests in Italy already saw the organisation of a large migrant rally, which he identifies as the first encounter between migrant organisations and the "global movement»:

[...] the demonstration on 19 July 2001, which opened the protests against the G8 meeting in Genoa with the slogan «Freedom of movement - freedom without boundaries ", has put the issues of migrants before the "global movement " born in Seattle for the first time ${ }^{66}$.

The European Social Forum (ESF), the regional expression of the so-called Global Justice Movement, has thus been strongly influenced by anti-racist and pro-migrant themes and, reciprocally, anti-capitalist events and social forums have been important moments in the development of pro-migrant groups and networks working transnationally in Europe. Most of the participants had directly participated in an ESF or another large anti/alter-globalist gathering, and the discourse, analysis and tactics of the anti-capitalist movement have had a strong influence on the ways in which these groups understand themselves and their struggle and design their actions and tactics. This might not be immediately obvious with all the interviewed groups, yet participants recognised the relevance of the anti-capitalist critique in order to understand the EU's immigration and border regime ${ }^{67}$. For some, the connections to the alter- and anti-globalist movement were clear. One participant stated : "we are anti-capitalist, feminist, anti-debt of the third world. These are our values. But we also are action-oriented in our local context. We merge the local and the global ${ }^{68}$. Another one also stipulated that: " one cannot understand migrations today without internationalising the issue. This is why we have a global, in fact alter-global, approach "69.

${ }^{66}$ MezZadRa Sandro, «The Right to Escape ”, Ephemera, 2004, vol. 4, n’3, p. 268.

${ }^{67}$ For example, MRN participant explained that the official narrative of his organisation tended to be more liberal and human rights-oriented but that it didnt invalidate a critical understanding of global migration nowadays. David, Interview with Céline CANTAT, 27 June 2012

${ }^{68}$ Sonia, Interview with Céline CANTAT, 7 September 2012.

${ }^{69}$ Michel, Interview with Céline CANTAT, 19 September 2012. 
In particular, it is clear to them that the border control practices of a given $\mathrm{EU}$ member state cannot be seen as simply the expression of an unjust national government. Rather, all the groups and networks inscribe their analysis within a larger reflection on the roles of borders globally, and their relationship with other global dynamics of domination and exploitation. Another aspect is the use by pro-migrant groups and networks in Europe of tools and tactics developed by anti-globalisation activists, such as transnational mailing lists and forms of action directed against non-state actors. The intersection between the anti-globalisation movement's politics and tactics and the particular traditions and cultures of the various groups participating in the research is a complex one but it has been a key structuring factor for migration struggles in Europe.

Finally, the institutional terrain on which these groups and campaigns are fighting diverges from that of previous pro-migrant initiatives. The participant groups and campaigns exist in particular local and national settings operating through their own political institutions but, at the same time, they all engage in a transnational political praxis. As we will see, the transnationalisation of their work has been the result of the realisation that immigration and asylum controls had changed and had to be fought at different levels and by addressing different actors - in particular that there was a need to fight beyond national boundaries and to confront trans- and supranational institutions. The evolution of the centres of power and decision-making into a multi-layered and complex transnational and intergovernmental assemblage has thus called for new structures and tactics in order to efficiently address the new political and institutional setting in which they operate.

\section{The emergence of trans-European pro-migrant activism}

The harmonisation of legislative frameworks governing issues related to migration and asylum has been a key area of cooperation between EU member states at least since the 1985 Schengen Agreement. The rationale for Europeanising immigration and asylum policies was that the free movement of people within the EU/EC space could only happen if, first, all member states applied identical criteria regarding entry requirements into their territory for "third country nationals" and, second, if the controls which had been waived at the EU's internal borders were reported and reinforced at its external borders. These legislations, which had started as inter-governmental regulations, were fully incorporated into European legislation with the 1997 Treaty of Amsterdam. The Treaty was implemented at the 1999 Tampere Summit, which was strongly criticised by European civil society organisations for its secrecy, lack of transparency and the association it made between « immigration » and 
"security " " $^{70}$ Subsequently, the harmonisation was further codified with the 2006 Schengen Borders Code ${ }^{71}$ and the 2010 Schengen Visa Code ${ }^{72}$ which legislate on border surveillance, joint controls and cooperation between member states regarding border checks and govern the role of the European external border agency, Frontex.

Several participants explain that it was not until the mid- or late 1990 s that they took full measure of what was happening at the EU level. They acknowledge feeling concerned following the 1985 signature of the Schengen agreement, in particular as it failed to address the issue of the status of "third country nationals » and started to refer to the reinforcement of Europe's external borders, but it was not until the 1992 Treaty of Maastricht, which created the EU and European citizenship as an exclusively derivative status, that the discriminatory and exclusive nature of the Union was fully grasped. Soon after Maastricht, the process of Europeanisation of immigration and asylum laws was initiated, boosted by the 1995 implementation of Schengen. This process encouraged closer collaboration between activists in different EU member states, both to exchange information in order to understand what the effects of these developments were and to share ideas about how to resist them. A participant from Gisti summarised these evolutions as follows:

\begin{abstract}
At Gisti, there was a preoccupation since the late 1980s [...] regarding what would come out of the Schengen Agreement. [...] But it was really difficult to work with our traditional associative partners, because all this seemed very theoretical for these partners [...] The French government never publicly announced the negotiations or what was being talked about in Brussels about the implementation of this Schengen Area [...] But we quickly anticipated that from this system would come out many things which would have rather serious implications, and that we had to be ready for what would come next. And thus to find partners elsewhere, outside France $[\ldots]^{73}$.
\end{abstract}

While it might have been the case that, at first, the developments were going unnoticed in France, participants in Italy which, like other Mediterranean countries, was suddenly turned into a border guard country for western and northern European member states, draw a very different picture :

70 STATEWATCH, "The Story of Tampere ", Statewatch briefing, 2003, available on the following website: http://www.statewatch.org/.

"Schengen Borders Code, Regulation of the European Parliament and of the Council of 15 March 2006 establishing a Community Code on the rules governing the movement of persons across borders, (EC) $n^{\circ} 562 / 2006$, Official Journal of the European Union, 13 April 2006, L 105, pp. 1-32.

${ }^{72}$ Schengen Visa Code, Regulation of the European Parliament and of the Council of 13 July 2009 establishing a Community Code on Visas, (EC) n 810/2009, Official Journal of the European Union, 15 September 2009, L 243, pp. 1-58.

${ }_{73}$ Chantale, interview cited. 


\begin{abstract}
In Italy, until the mid 1980s, we didn't have any immigration law [...]. But that changed very rapidly after 1995, when the Schengen Agreement was coming into place, and ltaly was told it had to adopt immigration policies that were along the lines of those that existed in northern European countries. Not only the law changed, there was a discourse to go with it, and you could see the change in people's attitude, you could see racist graffiti appearing on the walls [...] You know, there was definitely a new form of racist discourse in the media, by the politicians, that was being pushed forward, in the name of Europe. So we had to tackle this ${ }^{74}$.
\end{abstract}

It is on the occasion of the 1999 Tampere summit that, for the first time, these diverse experiences were brought together by activists. Two No Border activists remember the days leading up to the formation of the No Border network before 1999 as follows :

It all began with a meeting in Amsterdam, at the margins of a big demonstration against the EU summit in 1997 [...] The priorities and objectives of the political work in each country were gravely different, but what the groups had in common was the demand for practical, political intervention at the base i.e. grassroots politics. The new network was [...] concerned with systematically creating the preconditions for a Europe-wide collaboration, whose purpose was in the first place to enrich the every-day activities in each and every country [...] in 1999 the network was renamed «Noborder » and relaunched with the European-wide protest action to mark the occasion of the EU's special summit « justice and the interior » in Tampere [...] A common European day-of-action was arranged [...] to protest in a decentralized but coordinated manner against a new chapter in the politics of separation: [...] more exclusion, more control, more deportation ${ }^{75}$.

For these activists, the word Tampere became shorthand for the Europeanisation of immigration and asylum policy. It came to stand for the very process whereby a certain Europe, based on a system of segregation and discrimination and on a discourse of exclusion, was taking shape. It was a key moment in the history of many of the autonomous migrant solidarity groups : from then on, they started to consistently try "to match the level of the attack " ${ }^{76}$. Following the Tampere counter-demonstrations, the European No Border network emerged. 1999 was also the year of PICUM's establishment in Brussels. PICUM came about at the initiative of a group of grassroots organisations from Belgium, the Netherlands and Germany, which shared

${ }^{74}$ Zak, interview with Céline CANTAT, 23 July 2012. Similarly, in Portugal, the post-Salazar immigration laws passed in the mid 1980s had to be strongly tightened under pressure from the EU in 1993, in preparation for the implementation of Schengen.

${ }^{75}$ SCHNEIDER Florian and Kopp Hagen, "A Brief History of the Noborder Network », Tactical Media Files, available on the following website : http://www.tacticalmediafiles.net/.

${ }^{76}$ Sean, interview with Céline CANTAT, 16 July 2012. 
similar concerns regarding the lack of protection for undocumented migrants in the new European legal framework on immigration and asylum. A PICUM participant explained that :

\begin{abstract}
As the laws around migration were being transferred into the legal structure of the EU, groups in various member states realised that [...] the issue of undocumented migrants was left out of these juridical developments and that they would not gain any form of protection through the process of Europeanisation. We felt undocumented migrants and the problems they face had to be defended in the EU, and the best way for us to have leverage was to join forces and literally " turn up the volume ": make our voices louder by shouting together ${ }^{77}$.
\end{abstract}

Tampere called itself a summit on "freedom, justice and security ", presented as core tenets of the European project. But activists were quick to denounce that the quest for a European identity was being led at the expense of many other European residents : all those who did not have citizenship in one of the member states. European citizenship did not therefore move away from the exclusionary features of national identity discourses but, in fact, added an additional layer of exclusion for non-citizens.

\title{
Pro-migrant activisis and Europe : wither European identity ?
}

Since Tampere, these pro-migrant activists have engaged in a growing number of transnational campaigns, crossborder networks and pan-European actions. If my fieldwork evidenced an increasing "contentious practice of Europe " by pro-migrant activists, what however is the relationship between this "practice of Europe " and the European Union? Do activists put forward sets of propositions to reform and ameliorate the features of the European Union they mobilise against? Do they offer alternatives to these exclusionary understandings of European identity and citizenship ?

While the term "Europe " was comfortably referred to when I was asking participants about which aspects of Europe they opposed, it became a more complicated concept when I tried to elicit positive or alternative representations of what "Europe» or the Union could be/ become. This meant two things in practice : first, that references to European values, identity, citizenship as frames to propose inclusive models of membership were overall absent. In turn, I had to bring the terms to the table and thus actively participated in the co-production of the discussion on Europe futures. Second, in response to the question : "how do you relate to European identity? " or «do you feel 
European?", the most common response was : "what do you mean by Europe? " or, as participant Yasmin put it, "which aspects of Europe are we talking about exactly? ${ }^{78}$. It had not been the case when I had asked such questions as "what do you think of Europe's immigration policies? " or "tell me about your work around European borders ».

This phenomenon seemed to be linked to a conceptual difficulty in " imagining Europe » and to an overpowering uncertainty regarding what "Europe as a whole» meant. While concrete European measures could be identified through their material impact, giving a broader meaning to Europe was a challenge. In turn, this seems to point to the fact that activists did not consider Europe as a pertinent political space for the formulation of claims and radical propositions. In general, participants positioned themselves cautiously toward the idea of Europe and their answers were marked by a level of indeterminacy. Sonia for example told me:

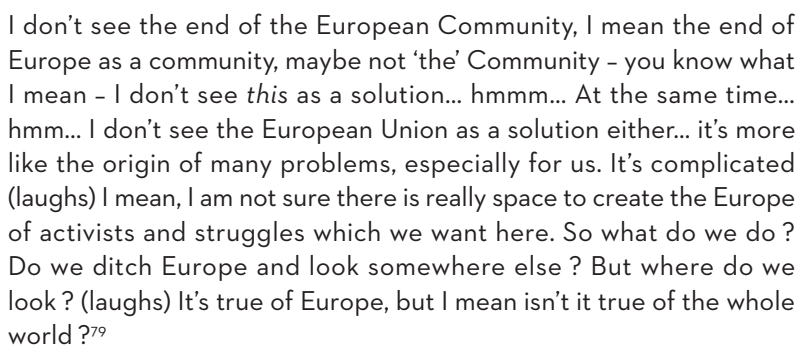

A participant told me that the European project was characterised by such strong contradictions that it became an "unusable word beside using it to denounce its damaging effects $"^{80}$. Many of them also mentioned a discursive monopoly over the term «Europe » by the European Union which made it a "saturated " term with little potential for radical claim making:

$$
\begin{aligned}
& \text { It is impossible for us, I mean for my generation at least, to think of } \\
& \text { Europe without having the European Union in mind. I see the EU has } \\
& \text { a capitalist class project and I reject it. So I don't really think in terms } \\
& \text { of Europe, European identity and so on... I have other references - I } \\
& \text { am more inclined toward global solidarity }{ }^{81} \text {. }
\end{aligned}
$$

Others extended a critical reading to Europe as a history and as an idea :

I was living in South America for a few years [...] I wanted to escape
from everything I associated with Europe, with this country, with

\footnotetext{
${ }^{78}$ Yasmin, interview with Céline CANTAT, 2 July 2013.

79 Sonia, interview cited.

${ }^{80}$ Martine, interview with Céline CANTAT, 12 September 2013.

${ }^{81}$ Tony, interview with Céline CANTAT, 30 Auguest 2012.
} 
imperialism and capitalism [...] I saw Europe as involved in a system of wealth, privilege, power and nationalism that I really didn't identify with...82

Overall, the narrative that I have re-constituted through the various stories and testimonies collected is one of disengagement from Europe, both as a project and as notion, articulated by a majority of participants. I chose the term "disengagement " because many of the participants came to this conclusion following a series of disillusionments vis-à-vis the European project - which must be distinguished from other forms of (nationalist) Eurosceptism. As put by participant Sean : " the good thing about being an anarchist is that I do not need to explain that I don't like Europe because I prefer the state ! ${ }^{83}$.

This " disengagement narrative " had several variables : some participants observed that the more they worked against some of the effects of the EU in the area of immigration, the less they believed the Union could be reformed. Others explained that the frame of debates and the process of decision-making in the EU were biased in such a way that one could only be heard if they adjusted to what is audible to the EU, thus making radical claims unspeakable. Participants also spoke of the feeling that working with the European institutions amounted to "being co-opted" and that this realisation had led them to formulate claims and undertake activities outside the frame of the European Union. Some mentioned that, through activist experiences with non-Europeans, their sense of belonging and solidarity had been extended to become a broader radical cosmopolitanism which refuses national as well as European borders.

Among those, a number of participants developed sophisticated arguments about the interrelation between situated, local struggles tackling "the expression of Europe as it is manifested to us " ${ }^{84}$ and global solidarity in which European borders had little relevance. A striking example was that of an emerging discourse about Mediterranean identity as a source of mobilisation in solidarity with migrants. Several participants referred to a "two-shored Mediterranean », which displaced frames of belonging toward the south to highlight similarities rather than conflict with migrants and which included groups and networks working on both sides of the Sea. These narratives enabled activists to develop counter-positions from which various local and regional sites of resistance emerged. At the same time, their narratives were also underpinned by internationalist or (critical) cosmopolitan identi- 
ties. As put by participant Marco : " we are here because we are all citizens of the world $"^{85}$. In the same vein, participants explained that the transnationalisation of their practices was European in shape, as they acted where the manifestations of the EU border regime were the most visible, but that their concern was not to shadow Europe but to follow the lines of movement of migrants and hence to extend well beyond European borders.

\section{Conclusion}

In conclusion, a transnational movement of solidarity with migrants has been in formation in the EU over the last two decades. It has been characterised by the increasingly cooperation of pro-migrant groups operating in different national contexts, a growing crossborder coordination of actions and campaigns and the multiplication of transnational networks. While increasingly trans-European in shape, this movement is not however structured around shared narratives of alternative European futures or counter-discourses of Europe and European identity. This " dearth of Europe " is related to activists' perception that the EU is too contradictory to be grasped, or that it is too strongly embedded within global capitalist structures, and hence cannot be reformed. Activists also developed an understanding of how neoliberal Europe brought about racialised patterns of marginalisation and exploitation, to which immigration and border controls were integral. Overall, activists' accounts of the European Union pointed to a process of ideological disengagement from a project they felt shared little with the forms of internationalism or cosmopolitanism they defended. This brings us back to the critical political economy of European construction that I developed in the first part of this article, and which highlighted the tension between national organisation and supranationalisation of capital in the EU. Rather than narratives of Europe, the discourses mobilised by activists to frame their activism brought together local experiences and global struggles in a fashion that challenged the geography of borders and othering of the EU. Sometimes inspired by local or regional popular history and memory, these narratives were connected by a common ideal of "world citizenry " sometimes inspired by earlier traditions of internationalism or by more recent alter-globalist struggles. 